\title{
Hepatotoxicity of Methotrexate and the Possible Ameliorative Effect of L-Carnitine:
}

\section{Ultrastructural Study}

\author{
M.A. Ashry ${ }^{1}$, S. M. Kadry ${ }^{1}$, N. R. Abuzeid ${ }^{2}$ and N. A. Algaw ${ }^{3}$
}

1.Zoology Department, Faculty of Women for Arts, Science and Education, Ain Shams University

2. Electron Microscopy Laboratory, Ain shams Specialized Hospital ${ }^{2}$

3.Biology Department, Faculty of Science, El-Margeb University, Libya ${ }^{3}$

\begin{abstract}
Methotrexate (Mtx) is widely used in various cancer and inflammatory diseases. Hepatotoxicity is the most serious side effect in long-term Mtx treatment. Therefore, the present study aimed to investigate the protective effect of L-Carnitine against Mtx-induced injury in rat's hepatocytes. Fifty male albino rats, each weighing $120-130 \mathrm{~g}$ were used. The experimental animals were equally divided into five groups , 10 rats each, and treated intraperitoneally (twice /week) as follows : (1) rats did not receive any treatment (control group ); (2) rats given 300mg L-Carnitine $/ 100 \mathrm{~g}$ b.w. for 4 weeks ; (3) rats given $0.045 \mathrm{mg}$ Mtx /100g b.w. for 4 weeks ; (4) rats given $0.045 \mathrm{mg}$ Mtx $/ 100 \mathrm{~g}$ b.w. with $300 \mathrm{mg} \mathrm{L}-$ Carnitine $/ 100 \mathrm{~g}$ b.w. for 4 weeks ; (5) rats given $0.045 \mathrm{mg}$ Mtx $/ 100 \mathrm{~g}$ b.w. for 4 weeks then given 300mg L-Carnitine $/ 100 \mathrm{~g}$ b.w. for other 4 weeks.

In Methotrexate- treated group, the ultrastructural study on hepatocytes revealed pyknotic nuclei with abnormally electron-dense chromatin, irregular nuclear envelopes, electron-dense mitochondria and fragmented rough endoplasmic reticulum.In addition to dilatation and congestion of the hepatic sinusoids as well as increase in lipid droplets and collagen fibers. Rats co-treated with L-Carnitine against Mtx showed significant improvement in the ultrastructure abnormalities of hepatocytes caused by Mtx. On the other hand, mild to moderate improvement in hepatocytes were observed in the group treated with Mtx followed by L-Carnitine. These results indicated that co- and post L-Carnitine treatment can diminish Mtx-induced liver ultrastructural injuries. The beneficial effect was more pronounced in L-Carnitine co treated with Methotrexate.
\end{abstract}

Key words: Liver, Methotrexate, L-Carnitine, Ultrastructural study.

*Corresponding author :Shadia Mohamed Kadry, Email: mhgawad11@yahoo.com 


\section{Introduction}

Methotrexate (Mtx), a folic acid antagonist, is a chemotherapeutic agent widely used in the treatment of some types of cancers and various inflammatory diseases such as psoriasis and rheumatoid arthritis. However, the efficacy of this agent in high doses has been associated with hepatotoxicity (Johovic et al., 2003; Cetinkaya et al., 2006; Erdogan et al., 2015).

Mtx is metabolized and stored in hepatocytes in the polyglutamated form (Chladek $\boldsymbol{e t}$ al., 1997) .The presence of higher levels of polyglutamates causes a longer intracellular presence of the drug, and this has been suggested as a mechanism for hepatotoxicity (Kremer et al., 1986).

The mechanisms of Mtx toxicity are not yet fully understood, but recent studies have shown that a decrease in the levels of cellular glutathione (GSH) and oxygen radicals are linked with the development of Mtx-induced toxicity ( Johovic et al., 2003 ; Cetinkaya et al., 2006; Sener et al., 2006 ; Cetin et al., 2008; Erdogan et al., 2015).It was demonstrated that cytosolic nicotinamide adenosine diphosphate (NADP)-dependent dehydrogenases are inhibited by Mtx, suggesting that the drug decreases the availability of NADPH in cells. Under normal conditions, NADPH is used by glutathione reductase to maintain the reduced state of GSH, an important cytosolic antioxidant that protects cells against reactive oxygen species (ROS). Thus, the significant reduction in GSH levels induced by Mtx therapy leads to reduction in the level of the antioxidant enzyme defence system, sensitizing the cells to ROS. Considering the relationship between GSH and the deleterious effects of Mtx, interest has focused on antioxidant compounds that can either stimulate GSH synthesis or act as direct antioxidants (Soliman, 2009).

L-Carnitine (LC) is a small water-soluble molecule which plays an important role in fat metabolism. It is essential for the normal mitochondrial oxidation of fatty acids and excretion of acyl-coenzyme A (acyl-CoA) esters and affects adenosine triphosphate levels (Vanella et al., 2000). L-Carnitine has antioxidant activity and metal-chelating properties

(Srinivas et al., 2007; Salama et al., 2012; Salama et al., 2013). So, it has the ability to scavenge superoxide anion and inhibit lipid peroxidation, thereby conferring protection against damage induced by hydrogen peroxide (Panneerselvam and Kumaran ,2006). Stabilization of the mitochondrial membrane leads to increase in the supply of energy to the organelle and protect the cell from apoptotic death.

The aim of the present study was to evaluate whether co- or post- L-Carnitine treatment has any beneficial effect on MTX-induced hepatotoxicity in rats.

\section{Materials and Methods}

\subsection{Experimental animals :}

Fifty male albino rats (Rattus norvegicus) their weight ranging from 120-130 g, were obtained from the animal house of Faculty of Medicine, Ain Shams University. The animals were placed in cages, fed on laboratory rodent chow and tap water. 


\subsection{The Drugs :-}

1) Methotrexate (Mtx, 4-amino-N10-methyl folic acid), a folic acid dihydrofolate reductase inhibitor, affects primarily the tissues that are growing most rapidly. Methotrexate was obtained from Sigma Pharmaceutical Industries, Egypt as injections.

2) L-Carnitine ( $\beta$-hydroxy- $\gamma-\mathrm{N}$-trimethylaminobutyric acid) is a cofactor required for transport of long-chain fatty acids into the mitochondrial matrix, where they underdo $\beta$-oxidation for cellular energy production. L-Carnitine is found in animal food sources. L-Carnitine is obtained from the Egyptian Pharmacists Company as injection. ( Tousson et al. 2014 )

\subsection{Experimental animal grouping:}

The animals were divided into 5 groups, 10 rats each:(1) The rats did not receive any treatment (control group ); (2) The rats given 300mg L-Carnitine $/ 100 \mathrm{~g}$ b.w. for 4 weeks ; (3) rats given $0.045 \mathrm{mg}$ Methotrexate $/ 100 \mathrm{~g}$ b.w. for 4 weeks ; (4) The rats given $0.045 \mathrm{mg}$ Methotrexate $/ 100 \mathrm{~g}$ b.w. with 300mg L-Carnitine $/ 100 \mathrm{~g}$ b.w. for 4 weeks ; (5) The rats given $0.045 \mathrm{mg}$ Methotrexate $/ 100 \mathrm{~g}$ b.w. for 4 weeks then given $300 \mathrm{mg}$ L-Carnitine $/ 100 \mathrm{~g}$ b.w. for other 4 weeks . Rats of all groups were injected intraperitoneally twice per week.

\subsection{Transmission electron microscopy study.}

For electron microscopical investigation, freshly-excised pieces of the liver tissue were dissected to about $1 \mathrm{~mm}^{3}$ in size and fixed in $5 \%$ glutaraldehyde prepared in $0.1 \mathrm{M}$ sodium cacodylate buffer for 4 hours at room temperature. Fixed specimens were then washed in $0.1 \mathrm{M}$ cacodylate buffer three times, 15 min for each.

The specimens were post-fixed in $1 \%$ buffered osmium tetroxide (OsO4) for $1-2$ hours at $4^{\circ} \mathrm{C}$. The tissue specimens were then washed twice in $0.1 \mathrm{M}$ cacodylate buffer three times, 15 min for each, then dehydrated in ascending grades of ethyl alcohol. The absolute alcohol was replaced by propylene oxide via a stepwise series of ethanol.

Dehydrated specimens were embedded in an epoxy resin then were infiltrated at room temperature in a mixture of epoxy resin and propylene oxide at $60^{\circ} \mathrm{C}$ for 48 hours and then allowed to attain room temperature.

Using a stereomicroscope, the mounted blocks were trimmed with razor blades to give a trapezoid-shaped face of less than $1 \mathrm{~mm}$ width and height as much as possible. The blocks were trimmed and sectioned at $1 \mu \mathrm{m}$ thickness on Leica Ultracut UCT Ultramicrotome using a glass knife.

Semi -thin sections were stained with toluidine blue and examined with the light microscope. The specimens were then re-trimmed to the selected region and ultrathin sections $(60-90 \mathrm{~nm}$ thickness) were cut, on the same above ultramicrotome using a diamond knife, and picked up on copper grids. 
The sections were double stained using uranyl acetate and lead citrate. After staining, the grids were washed in distilled water and then dried on filter paper.

The stained sections were examined and photographed using a JEOL/1010 electron microscope at the "Electron Microscope Unit", in the Faculty of Medicine, Ain Shams University, Cairo, Egypt.

\section{Results and Discussion}

\subsection{Results}

Examination of liver sections of the control animals showed the hepatocyte nucleus with circular smooth envelope and normal distribution of euchromatin. The cytoplasm contains the usual organelles of which rod- like or rounded mitochondria with intact cristae. Parallel cisternae of rough endoplasmic reticulum (rER), plenty amounts of glycogen and smooth endoplasmic reticulum (sER) were seen (Figure1).L-Carnitine group revealed an identical ultrastructural view similar to that demonstrated by the control group (Figure 2).

Liver sections administrated methotrexate for 4 weeks revealed marked ultrastructural changes showing necrotic areas with eroded cell membranes. Nuclear lesions were observed as ill defined, electron translucent nuclei, with irregular outer membranes. Also pyknotic nuclei were prominent with shrunken and irregular outlines with abnormally electron dense chromatin. The hepatocyte cytoplasm contains shrunken, electron dense and malformed mitochondria. Rough endoplasmic reticulum with its associated ribosomes was essentially limited to scattered areas which showed fragmentation and severe damage. Dilated bile canaliculi and loss of hepatocyte microvilli were frequently observed. Also dilated, congested hepatic sinusoids, RBC's and collagen in the space of Disse were also prominent (Fig.3).

Sections of liver of animals treated with methotrexate and L-Carnitine for 4 weeks showed moderate improvement of the hepatocyte fine structure. Cell membranes and nuclear outlines of some hepatocytes restored the normal structural architecture. This was observed in most hepatocytes, while some others still showed malformation and irregularity. The majority of mitochondria appeared almost normal,with well-formed ultrastructural details and cristae mitochondrials, while others were still ill-defined and electron-dense. The rough endoplasmic reticulum appeared slightly dilated, and was slightly fragmented (Fig.4).

The liver sections of animals treated with methotrexate for 4 weeks followed by L-Carnitine for other 4 weeks showed only mild improvement and involved a fraction of organelles, while the majority remained damaged or ill-defined as a result of methotrexate toxicity. Some nuclei appeared almost normal with regular smooth nuclear envelope and chromatin, while others lost their normal electron density and appeared degenerative. Perinuclear rough endoplasmic reticulum was partially restored, showing parallel profiles, while the smooth endoplasmic reticulum was dilated or fragmented. Some mitochondria regained their structural details, while the majority were abnormally electron-dense and malformed. Cytoplasmic matrix contained irregular vacuoles of various sizes indicating vacuolar degeneration (Fig.5) 


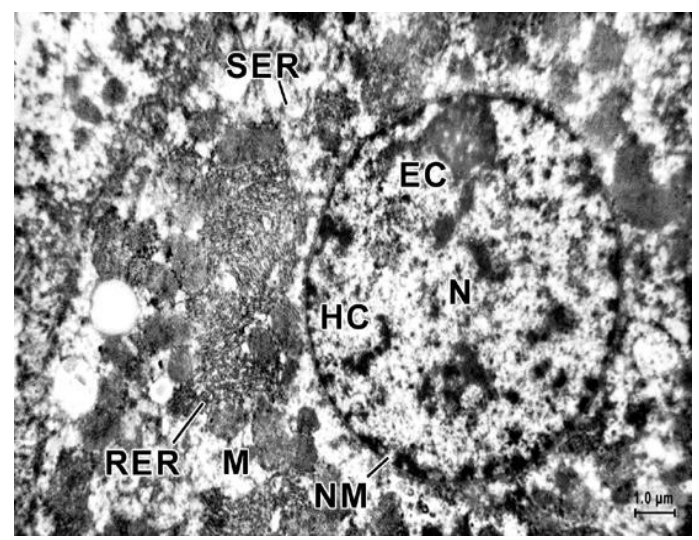

Fig.(1): Photomicrograph of a section from Control rat liver showing the nucleus of the hepatocyte $(\mathrm{N})$ with normal distribution of chromatin .The cytoplasm is rich in normal mitochondria (M).Notice the presence of well-developed cisternae of rER and smooth endoplasmic reticulum (sER). (X 6000).

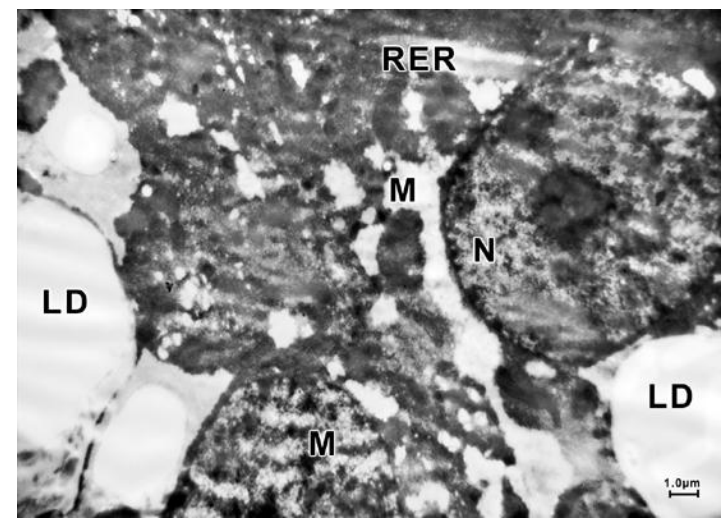

Fig.(3): Photomicrograph of a section in liver of rat treated with Mtx for 4 weeks showing the hepatocyte cytoplasm containing electron-dense mitochondria (M), fragmented RER ( $\uparrow)$ and lipid droplets (LD).(X 4000)

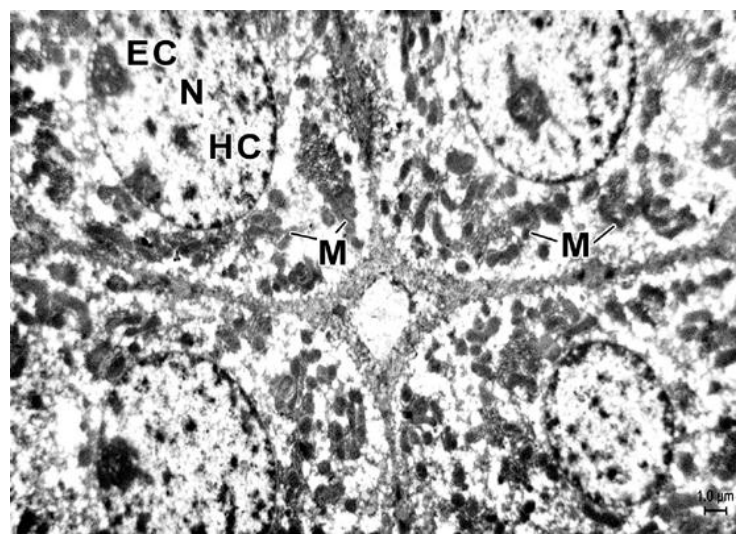

Fig.(2): Photomicrograph of a section in liver of rat treated with L-Carnitine for 4 weeks demonstrating normal nuclear configuration $(\mathrm{N})$ with electron dense chromatin and nucleoli. The cytoplasm appears normal with mitochondria $(\mathrm{M})$, rough endoplasmic reticulum (rER) and smooth endoplasmic reticulum (sER) (X 3000).

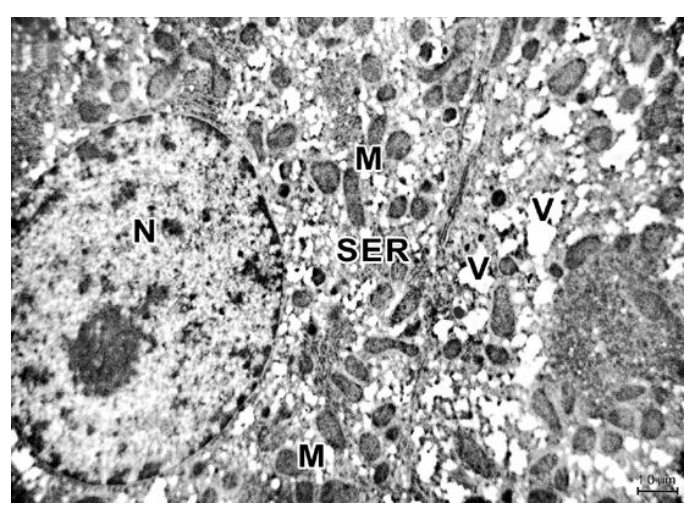

Fig.(4): Photomicrograph of a section in liver of rat treated with Mtx and L-Carnitine for 4 weeks showing almost normal structural architecture of the hepatocyte, normal mitochondria (M) with wellformed ultrastructural details. However, another hepatocyte showing cytoplasmic vacuoles (V) (X 6000). 


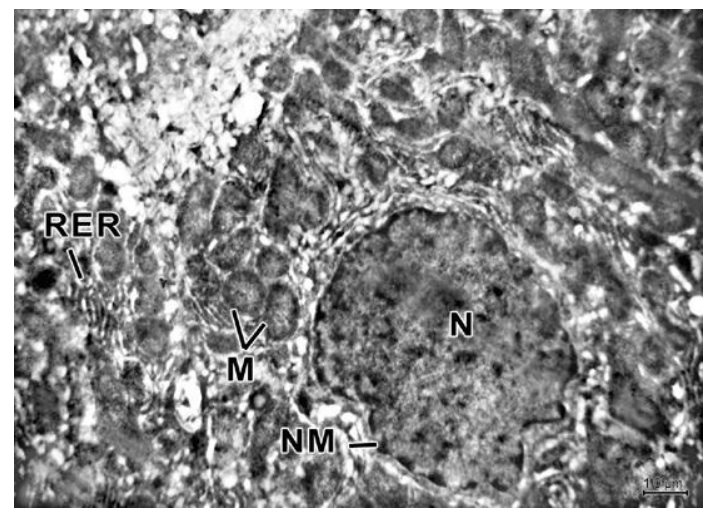

Fig.(5): Photomicrograph of a section in liver of rat treated with MTX for 4 weeks followed by L-Carnitine for other 4 weeks showing partial restoration of the hepatocytes appearance. The mitochondria (M) appear with almost normal structure, slightly dilated rough endoplasmic reticulum (RER). The nucleus (N) still shows irregular nuclear envelope.(X 6000).

\subsection{Discussion}

Administration of Methotrexate to male albino rats with dose $0.045 \mathrm{mg} / 100 \mathrm{~g} \mathrm{~b}$.w. twice per week for 4 weeks caused pathological alterations in the fine structure of the hepatocytes.

Electron microscopic examination of the liver ultrathin sections of rats given methotrexate showed a variety of mitochondrial abnormalities including pleomorphism, proliferation of mitochondria, swelling, and increase or decrease in the density of matrices. The present results were confirmed by Ali et al.(2005) who noticed proliferation of mitochondria that displayed a diversity in shape and size, as well as changes in the matrix and cristae. These changes, including the presence of flocculent wooly focal inclusions, were strongly suggestive of toxic injury resulting probably from a biochemically defective mitochondrial membranes since similar changes have been found in hepatocytes and other cells after administration of a variety of cytotoxic chemicals. Also, Hemmaid et al.(2015) reported that rats treated with a low therapeutic dose of methotrexate $(10 \mathrm{mg} / \mathrm{kg}$ bw) for 2,4 and 6 weeks showed pleomorphic mitochondria characterized by increased density of matrices and without discrimination of their cristae. Giant mitochondria (gigantism) appeared in an elongated shaped. Other mitochondria suffered degenerated matrices cristae and lysis of cristae similar to paracrystalline inclusions bodies. Deteriorated mitochondria were surrounded with fragmented cisternae of the rough endoplasmic reticulum. Also, in rats treated with the high dose of Mtx for 6 weeks mitochondria has fragmented cristae as seemed to be filled with degenerated inclusions and small spherical vacuolated parts.

The accumulation of many altered mitochondria and the increased oxygen consumption following HD-MTX infusion may be either a compensatory reaction occurring at the organelle level or the result of the lesion's high demands upon the cell's energy resources (Ghadially, 1997).

Rubin (2001) postulated that severe degeneration of cell organelles especially the mitochondria and the rough endoplasmic reticulum, could be attributed to the oxygen 
metabolites with deficiency of the protective enzymes from the liver following drug treatments. Erdogan et al. (2015) suggested that Mtx increased MDA levels which confirmed the oxidative stress and explained the tissue damage.

Toxicity studies with methotrexate highlight the role of oxidative stress in causing toxicity on the liver, kidney, heart and other organs (Tousson et al.2014).

In the current work, pyknotic nucleus with homogeneous distribution of chromatin as well as irregular nuclear envelope, fragmented rough endoplasmic reticulum, increased lipid droplets and collagen fibres were common features of hepatocytes in response to Mtx treatment. In the same concern, Ali et al. (2005) observed the dispersion of polyribosomes, disruption of GER, vesiculation and proliferation of SER and changes in the distribution of the nuclear chromatin in hepatocytes of rats treated with Mtx. Also Hinton and Grasso (1999) described similar ultrastructural changes after administration of other drugs with diverse pharmacological properties and chemical structures indicating that such alterations are generally not drug-specific.

Ali et al. (2005) stated that the glycogen content following HD-MTX treatment varied, with glycogen granules either being depleted or accumulated in large pools within the cytoplasm. Similar changes occurred in livers as a consequence of administration of several drugs and toxins. The granules were largely of the beta type, fine and less electron-dense than in the control livers.

Cytoplasmic vacuolation and cell swelling in certain hepatopathies in humans and experimental animals were also discerned by Crawford (2005) and Kumar et al., (2005) who reported that the hepatocytes in the affected zones became swollen, spherical, and vacuolated. Cytoplasmic vacuolation is known to develop when the cellular semi permeability is increased but not totally destroyed. Moreover, the possibility of an early manifestation representing an acute protective adaptation associated with the tolerance of the liver cells to acute hepatotoxic injury (Kumar et al., 2005).

In the present work, dilated bile canaliculi with loss of hepatocyte microvilli were observed and this is in accordance with the observations of Ali et al.(2005) who stated that HDMTX-induced striking changes in the cell membrane and microvilli of the hepatocytes. These changes included alteration in the microvilli, loosening of intercellular junctions, bleb formation and shedding of the plasma membrane. The intercellular junctional complexes play an important role in normal function of the liver and other organs (Hu et al., 2002; Velazquez et al., 2003).

In the present study, L-Carnitine treatment improved the ultrastructural abnormalities in liver cells related to MTX toxicity. It has been shown that L-carnitine was able to reduce liver damage in patients with nonalcoholic fatty liver disease (Chang et al., 2005). 
Previous studies demonstrated that hepatoprotective effects of L-Carnitine were associated with upregulation of antioxidant enzyme activities (Chang et al., 2005; Panneerselvam and Kumaran , 2006). Therefore, the improvement of the antioxidant enzyme activities that inhibit lipid peroxidation may explain the beneficial effects of L-Carnitine against hepatotoxicity. Furthermore, L-carnitine is a mitochondrial cofactor. By supplementing this cofactor, the mitochondrial toxicities can be corrected (Al-Nawakil et al., 2014).

\section{Conclusion}

In conclusion, it is worth mentioning that L-Carnitine proved to be more effective in ameliorating hepatotoxicity of Mtx when they are used simultaneously. Therefore, can be used as prophylactic than when used as therapeutic after stopping of Mtx.

\section{References}

Ali , S.Y.; Hassan, I.M. and Sadek, S. ,Ultrastructural changes in rat livers perfused in vitro and in vivo with a high dose of methotrexate. Histol.Histopathol., 20 (4):1131-1145(2005).

Al-Nawakil, C.; Willems, L.; Mauprivez, C.; Laffy, B.; Benmrad, M.; Tamburini, J.; Fontaine, H.; Sogni, P.;Terris, B.; Bouscary, D. and Moachon, L., Successful treatment of Lasparaginase-induced severe acute hepatotoxicity using mitochondrial cofactors. Leuk Lymphoma. ;55 (7):1670-1674(2014).

Cetin, A.; Kaynar, L.; Kocyigit, I.; Hacioglu, S.K.; Saraymen, R.; Ozturk, A.; Sari, I. and Sagdic, O., Role of grape seed extract on methotrexate induced oxidative stress in rat liver. Am. J. Chinese Med. 36: 861-872(2008).

Cetinkaya, A.; Bulbuloglu, E.; Kurutas, E.B. and Kantarceken, B., N-acetylcysteine ameliorates methotrexate-induced oxidative liver damage in rats. Med. Sci. Monit. 12: 4748(2006).

Chang, B.; Nishikawa, M.; Nishiguchi, S. and Inoue, M., L-Carnitine inhibits hepatocarcinogenesis via protection of mitochondria. Int. J. Cancer 113:719-729(2005).

Chladek, J.; Martinkova, J. and Sispera, L., An in vitro study on methotrexate hydroxylation in rat and human liver. Physiol. Res., 46: 371-379(1997).

Crawford, J., Liver and billiary tract. In: Robbins and Cotran Pathologic Basis of Disease. 7th ed. Kumar V., Abbas A. and Fausto N. (eds). Elsevier Saunders. Philadelphia. pp 877-937(2005).

Erdogan, E.; Ilgaz, Y.; Gurgor, P.N.; Oztas, Y.; Topal, T. and Oztas, E., Rutin ameliorates methotrexate induced hepatic injury in rats. Acta. Cir. Bras. 30:778-784(2015).

Ghadially, F.N., Ultrastructural Pathology of the Cell and Matrix. 4th Ed. ButterworthHeinemann. Boston. Oxford (1997). 
Hemmaid, K.Z.; Abd El Menem, O.M. and Said, M., Ultrastructural Perturbations in Hepatic Cells of Rats Induced by Methotrexate and the Prophylactic Role of Folic Acid Administration. Middle East J. Appl. Sci., 5(4): 950-964(2015).

Hinton, R. and Grasso, P., Hepatotoxicity. In: General and Applied Toxicology. 2nd ed. Vol. 2. Chapter 42. Ballantyne B., Marrs T. and Syversen T. (eds). McMillan Reference. London. pp 853-891(1999).

Hu, W.; Jones, P.; Upham, B.; Trosko, J.; Lau, C. and Giesy, J., Inhibition of gap junctional intercellular communication by perfluorinated compounds in rat liver and dolphin kidney epithelial cell lines in vitro and Sprague-Dawely rats in vivo. Toxicol. Sci. 68: 429-436(2002).

Johovic, N.; Cevik, H.; Sehirli, O.A.; Yegen, B.C. and Sener, G. Melatonin prevents methotrexate-induced hepatorenal oxidative injury in rats. J. Pineal. Res., 34: 282-287(2003).

Kremer, J.M.; Galivan, J.; Streckfuss, A. and Kamen, B. Methotrexate metabolism analysis in blood and liver of rheumatoid arthritis patients. Association with hepatic folate deficiency and formation of polyglutamates. Arthritis Rheum., 29: 832-835 (1986).

Kumar, V.; Abbas, A. and Fausto, N. Fobbins and Cotran Pathologic Basis of Disease. 7th ed. Elsevier Saunders. Philadelphia. pp 3-46(2005).

Panneerselvam, K.S. and Kumaran, S. L-Carnitine and alpha-lipoic acid improves mitochondrial function during ageing process. Clin. Nutr., 21: 48-60 (2006).

Rubin, E. : Essential Pathology . 3rd ed. Lippincott Williams \& Wilkins.(2001 )

Salama, A.F.; Kasem, S.M.; Tousson, E. and Elsisy, M.K. Protective role of L-carnitine and vitamin E on the kidney of atherosclerotic rats. Biomedicine \& Aging Pathology., 2: 212-215 (2012).

Salama, A.; Kasem, S.; Tousson, E. and Elsisy, M.K., L-carnitine and vitamin E alleviate reproductive toxicity caused by triton WR 1339 in male albino rats. Toxicology and Industrial Health., DOI: 10.1177/0748233712472523(2013).

Sener, G.; Eksioglu-Demiralp, E.; Cetiner, M.; Ercan, F.; Sirvanci, S.; Gedik, N. and Yegen, B.C., L-Carnitine ameliorates methotrexate-induced oxidative organ injury and inhibits leukocyte death. Cell Biol. Toxicol. 22: 47-60(2006).

Soliman, M. E., Evaluation of the possible protective role of folic acid on the liver toxicity induced experimentally by methotrexate in adult male albino rats: Egypt. J. Histol., 3: 118 128(2009).

Srinivas, S.R.; Prasad, P.D.; Umapathy, N.S.; Ganapathy, V. and Shekhawat, P.S.,Transport of butyryl-L-carnitine, a potential prodrug, via the carnitine transporter OCTN2 and the amino acid transporter ATB $(0,+)$. Am. J. Physiol. Gastrointest. Liver Physiol., 293: 1046-1053(2007). 
Tousson, E.; Hafez, E.; Zaki, S. and Gad, A., P53, Bcl-2 and CD68 expression in response to amethopterin-induced lung injury and ameliorating role of L-carnitine. BIOPHA 3409 1-9(2014). Vanella, A.; Russo, A.; Acquaviva, R.; Campisi, A.; Di Giacomo, C. and Sorrenti, V., LPropionyl-carnitine as superoxide scavenger, antioxidant, and DNA cleavage protector. Cell Biol. Toxicol., 16: 99-104(2000).

Velazquez, J.; Frantseva, M. and Naus, C., Gap junctions and neuronal injury: protectants or executioners? Neuroscientist, 9: 5-9 (2003). 


\section{الملخص باللغة العربية}

\section{السمية الكبدية لعقار الميثوتريكسات و الوقاية المحتملة لمادة لـ كارنيتين : دراسة تركيبية دقيقة}

مديحة عبدالمنعم عثري ، شادية محمد قدري ، نادية راغب على أبوزيد² ، نجوى عبدالقادر أحمد القعو 3

$$
\begin{aligned}
& \text { 1.قسم علم الحيوان ـ كلية البنات للآداب و العلوم و التربية ـ جامعة عين شمس }
\end{aligned}
$$

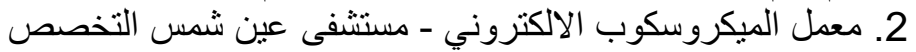

$$
\begin{aligned}
& \text { 3.قسم الاحياء ـ كلية العلوم - جامعة المرقب - ليييا }
\end{aligned}
$$

الميثوتريكسات احد العقاقير التى تستخدم على نطاق واسع في علاج بعض أنو اع السرطان و الأمراض الالتهابية .

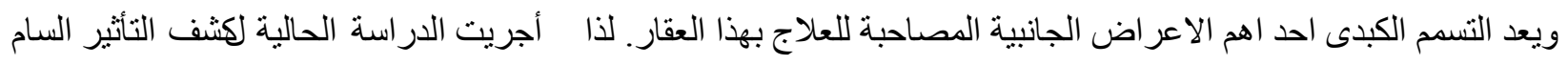

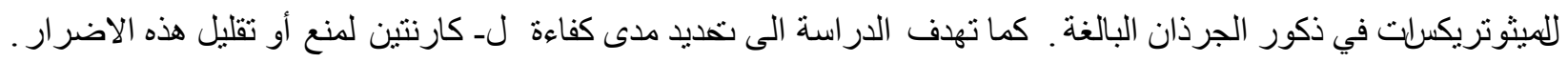

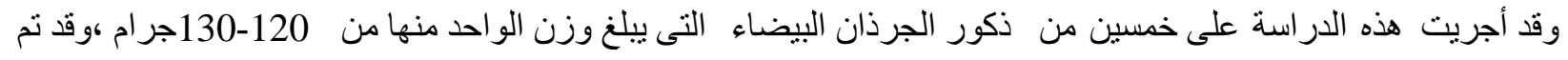

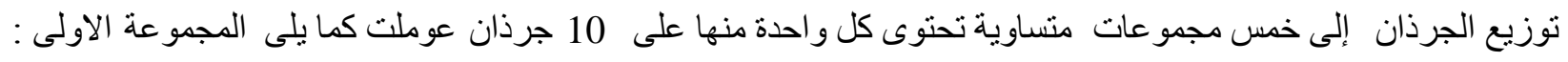

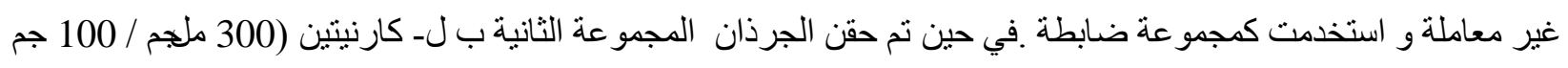

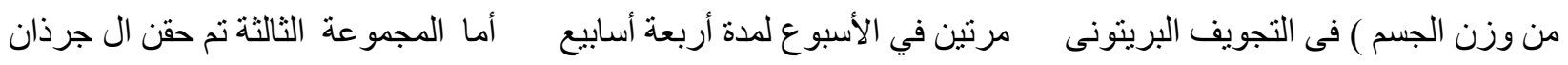

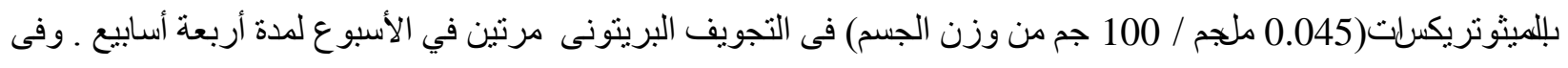

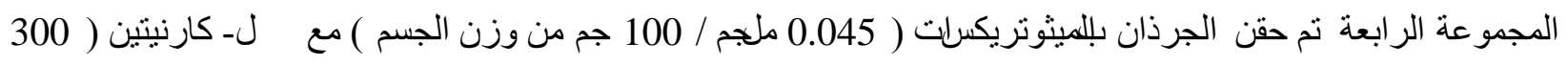

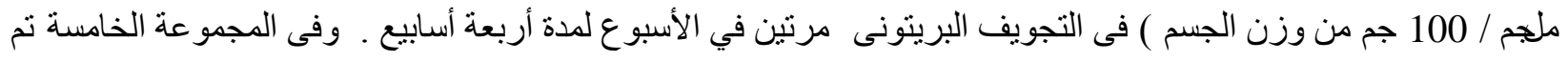

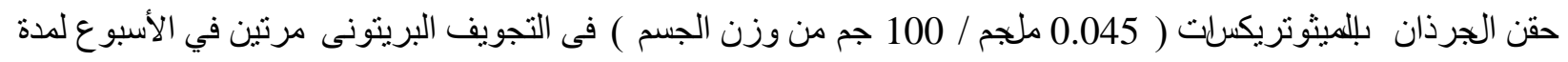

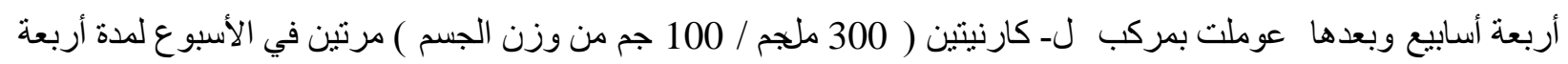
أسبابيع أخرى.

أوضحت الدر اسة التركيبية الدقيقة أن كل من مجموعة لـ كارنيتين و المجمو عة الضابطة غير المعاملة لم يظهر بها اية

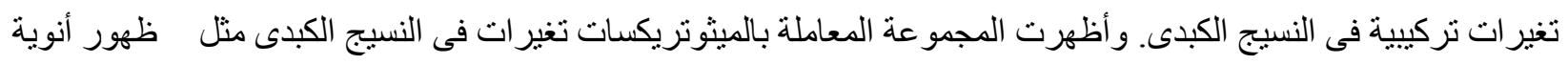

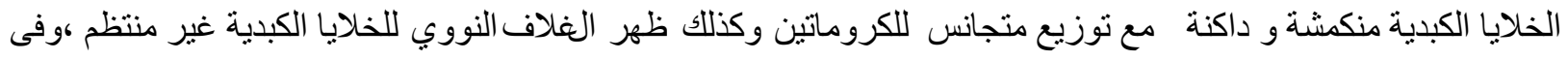

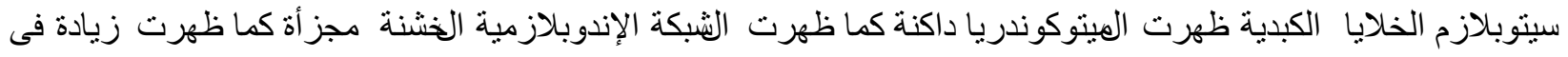

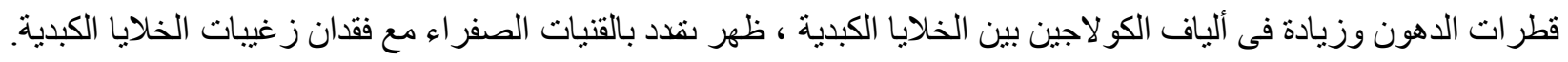

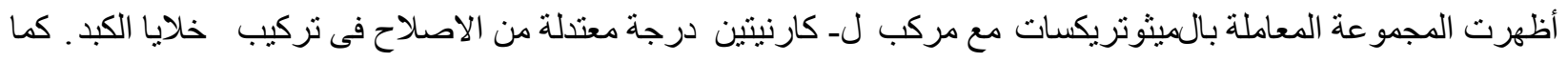

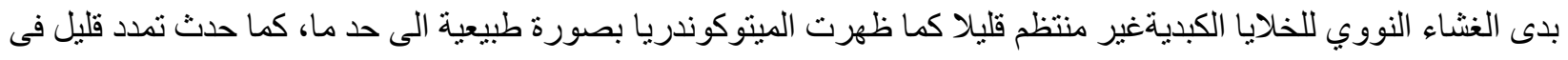

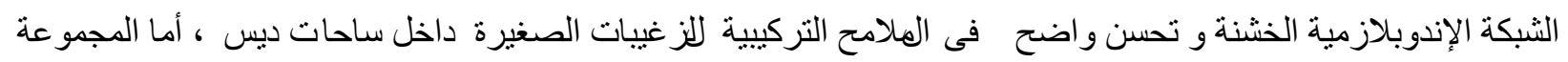


المعاملة بالميثوتريكسات أو لا ثم لـ كارنيتين أظهرت درجة متوسطة من الاصلاح في شكل الخلايا الكبدية حيث ظهرت أنوية الخلايا الكبدية أقرب الى الحالة الطبيعية و الغلاف النووي منتظم مع توزيع متجانس للكروماتين .وقد ظهرت الثبكة الإندوبلازمية الخشنة بصورة تكاد تكون طبيعية ، كما حدث تمدد فى الثبكة الإندوبلازمية الملساء ـ. وقد استعادت بعض من الميتوكوندريا شكلها الطبيعى ، في حين كانت الغالبية بشكل غبر طبيعي ـمن هذه الدراسة نستخلص أن كل من المعالجة المنز امنة و المتو الية بمركب لـ كارنتين مع الميثوتريكسات كان لها اثر محسنا على التركيب الدقيق لخلايا الكبد. وكان هذا التحسن اكثر فاعلية فى المجموعة المعالجة بمركب لـ كارنتين بالتز امن مع الميثوتريكسات. 